\title{
Prevalence of antibodies to lymphocystis virus in estuarine flounder Platichthys flesus
}

\author{
Kai Lorenzen ${ }^{1}$, Peter F. Dixon ${ }^{2}$ \\ ${ }^{1}$ Institut für Meereskunde, Düsternbrooker Weg 20, W-2300 Kiel 1, Germany \\ ${ }^{2}$ Ministry of Agriculture, Fisheries and Food, Directorate of Fisheries Research, Fish Diseases Laboratory, The Nothe, \\ Weymouth, Dorset DT4 1UB, United Kingdom
}

\begin{abstract}
Serological surveys were conducted on flounder Platichthys flesus L., 1758 populations in 2 German estuaries. The prevalence of antibodies to lymphocystis virus (seroprevalence) was determined by means of an enzyme-linked immunosorbent assay (ELISA). Both seroprevalence and antibody levels in lymphocystis virus antibody positive (seropositive) fish with no gross signs of disease increased with age. These findings suggest that recovery from lymphocystis is common and concomitant with the acquisition of some degree of immunity in the populations studied.
\end{abstract}

\section{INTRODUCTION}

Lymphocystis is a common iridovirus infection of many species of teleost fish. The pathology and epidemiology of the disease, in both laboratory experiments and the natural environment, have been well documented. Recent reviews have been given by Wolf (1988) and Anders (1989).

However, little is known about immunological aspects of the disease. Russell (1974) found antibody activity against the virus in sera of visibly infected plaice Pleuronectes platessa and flounder Platichthys flesus. Wolf (1962) reported that transmission of the virus to bluegills Lepomis macrochirus, previously exposed to the disease, was successful in only 2 out of 5 fish, whereas the virus was transmitted to all of 7 bluegills which received the virus for the first time. The lymphocystis lesions which developed in the former fish after reinfection remained smaller than those which had developed after the first infection. This suggested that a degree of specific immunity developed in these fish. In plaice, a strong humoral and cellular immune response develops late in the disease pathogenesis, upon the release of large amounts of pathogen from disintegrating infected cells (Roberts 1975).

Under aquaculture conditions, infected fish usually recover completely without significant mortalities (Matsusato 1975, Paperna et al. 1982, Tanaka et al.
1984, Masoero et al. 1986). The situation may be different in wild populations, where diseased individuals may suffer increased mortalities because of predation or adverse environmental conditions. In tagging experiments, Ryder (1961) found disease-related mortality to be negligible in walleye Stizostedion vitreum, although conversely Margenau et al. (1988) considered that lymphocystis might have caused mortality in another walleye population. If recovery from the disease is common in wild populations, a concomitant development of immunity can be expected to be an important factor controlling the dynamics of the disease in fish populations.

To determine the extent to which naturally infected fish develop a humoral response to the infection, we have conducted a serological survey of 2 estuarine Platich thys flesus populations, using an enzyme-linked immunosorbent assay (ELISA) to detect antibody activity against lymphocystis virus.

\section{MATERIALS AND METHODS}

Serum samples. Sampling of Platichthys flesus was conducted between April and July 1989 in the estuaries of the Elbe and the Eider, Germany. The flounders were caught by commercial beam trawl and also at the intake of the Brunsbüttel nuclear power plant. Blood was collected from the posterior cardiac vein, left to clot 
overnight at $4^{\circ} \mathrm{C}$, centrifuged and the sera stored below $-20^{\circ} \mathrm{C}$. Fish were aged from otolith readings.

Purification of lymphocystis virus antigen. Lymphocystis lesions were collected from infected flounders and stored at $-80^{\circ} \mathrm{C}$ in foetal calf serum. The purification procedure was adapted from Darai et al. (1983). Lesions were homogenized in TNE buffer $(0.01 \mathrm{M}$ tris[hydroxymethyl]methylamine, $0.1 \mathrm{M}$ sodium chloride, $1 \mathrm{mM}$ ethylenediaminetetra-acetic acid, $\mathrm{pH}$ 7.4) and centrifuged twice for $20 \mathrm{~min}$ at $1500 \times \mathrm{g}$. The supernatant was centrifuged through $30 \%$ sucrose for $1 \mathrm{~h}$ at $75000 \times \mathrm{g}$. The pellet was resuspended in TNE, overlayed on a 25 to $60 \%$ sucrose gradient and centrifuged for $2 \mathrm{~h}$ at $75000 \times \mathrm{g}$. Virus bands were harvested, diluted in TNE and centrifuged for $1 \mathrm{~h}$ at $75000 \times g$. Pellets mere resuspended in TNE.

Partial purification of flounder immunoglobulin (Ig). Flounder Ig was partially purified from pooled serum samples. Following lipid precipitation with $20 \%$ dextran sulphate 500 and $0.1 \mathrm{M} \mathrm{CaCl}_{2}$ (Bourne 1969), protein was precipitated in $50 \%$ saturated ammonium sulphate (SAS). The precipitate was washed 3 times in $55 \%$ SAS. After resuspension in phosphate buffered saline, pH 7.2 (PBS), precipitation and washing was repeated. The precipitate was redissolved and desalted by filtration through Sephadex G-25 M column (PD-10, Pharmacia). Proteins were separated on a $90 \mathrm{~cm}$ Sephacryl S-300 column (Pharmacia). The Ig was eluted in the first peak. Ig fractions possibly contaminated with proteins from the second peak were discarded, and the remaining Ig fractions were pooled.

Antiserum to Iymphocystis virus. Lymphocystis virus, at a concentration of $1 \mathrm{mg} \mathrm{ml}^{-1}$, was emulsified with an equal volume of Freund's complete adjuvant (FCA). A New Zealand white rabbit was given 2 intramuscular (i.m.) injections of $1 \mathrm{ml}$ emulsion each. These injections were repeated 4 and $6.5 \mathrm{wk}$ after the first injection, but using Freund's incomplete adjuvant (FIA). Blood was collected $4 \mathrm{wk}$ after the final injection and serum separated.

Antiserum to flounder Ig. The Ig was diluted to $1 \mathrm{mg}$ $\mathrm{ml}^{-1}$ and emulsified with equal volumes of FCA. A New Zealand white rabbit was given 2 i.m. injections of $1 \mathrm{ml}$ emulsion each, followed by further injections of $2 \times 1 \mathrm{ml} \mathrm{Ig}$ in FIA after 2, 4 and $10 \mathrm{wk}$. Seventeen weeks after the initial injection, $1 \mathrm{ml}$ of $\mathrm{Ig}$ at $1 \mathrm{mg} \mathrm{ml}^{-1}$ was injected intravenously. Blood was collected 5 and $8 \mathrm{~d}$ after the last injection.

Purification of rabbit $\gamma$-globulin and enzyme conjugation. The $\gamma$-globulin was extracted and purified from the rabbit anti-flounder Ig antiserum by 2 cycles of ammonium sulphate precipitation and washes, followed by desalting on a PD-10 column. The $y$-globulin was diluted to $1 \mathrm{mg} \mathrm{ml}^{-1}$ and conjugated with alkaline phosphatase E.C.3.1.3.1 (Type VII-NT; Sigma) as described by Clark \& Adams (1977). Glutaraldehyde was removed by filtration through Sephadex G-25 DNA grade (NAP-10 column, Pharmacia).

ELISA. Microtiter plates (Costar 5090) were coated with viral antigen both directly, and indirectly using rabbit anti-lymphocystis virus $\gamma$-globulin. In the latter case, anti-lymphocystis virus $\gamma$-globulin was diluted to $5 \mu \mathrm{g} \mathrm{ml} \mathrm{l}^{-1}$ in carbonate buffer ( $\mathrm{pH}$ 9.6) as described by Dixon \& Hill (1984). Wells were filled with $100 \mu \mathrm{l}$ of the coating solution, and the plates left overnight in a water bath (initially heated to $37^{\circ} \mathrm{C}$ and then switched off). Following two 3 min washes in PBS, plates were blocked with $200 \mu \mathrm{l}$ well ${ }^{-1}$ of $1.5 \%$ BSA in carbonate buffer for $1 \mathrm{~h}$ at $37^{\circ} \mathrm{C}$. After an initial quick rinse and four 3 min washes in PBS containing $0.05 \%$ Tween 20 (PBST) (the standard wash), $100 \mu 1$ of lymphocystis virus, diluted to $5 \mu \mathrm{g} \mathrm{ml} \mathrm{m}^{-1}$ in PBST containing $1 \%$ Nonidet P40, were applied to alternate rows of the plate and incubated for $1 \mathrm{~h}$ at $37^{\circ} \mathrm{C}$. This was again followed by the standard wash.

For direct coating, purified virus was diluted to $5 \mu \mathrm{g}$ $\mathrm{ml}^{-1}$ in coating buffer, $100 \mu \mathrm{l}$ well ${ }^{-1}$ applied to alternate rows of the plate, and incubated in the same way as the rabbit anti-lymphocystis virus Ig. After two 3 min washes in PBS, blocking was performed as above.

Serum samples were diluted $1: 10$ in PBST with $1 \%$ $\mathrm{BSA}, 100 \mu \mathrm{l}$ applied in duplicate to both virus-coated and noncoated wells, and incubated for $1 \mathrm{~h}$ at $25^{\circ} \mathrm{C}$. A positive control sample was included on all plates. This was followed by the standard wash.

The anti-flounder Ig enzyme conjugate was diluted 1:1800 in PBST with 1\% BSA, $100 \mu \mathrm{l}$ was added to each well and incubated for $1 \mathrm{~h}$ at $25^{\circ} \mathrm{C}$, followed by the standard wash.

Substrate ( $p$-nitrophenyl phosphate) in 10\% diethanolamine buffer (pH 9.8), $200 \mu$ l well $^{-1}$, was incubated for $1 \mathrm{~h}$ at $37^{\circ} \mathrm{C}$. The reaction was stopped by addition of $50 \mu \mathrm{l}$ well $^{-1}$ of $3 \mathrm{M} \mathrm{NaOH}$.

The absorbance of the hydrolysis product was read at $405 \mathrm{~nm}\left(\mathrm{~A}_{405}\right)$, using an ELISA reader (Titertek Uniscan II).

Treatment of ELISA data. Test results were interpreted on the basis of the positive-negative ratio (pnr): the $A_{405}$ value of a serum sample in the virus coated wells divided by the $A_{405}$ of the same sample in the non-coated wells. The average $A_{405}$ value of the 2 replicates was used. The following procedure was adapted from Parkinson et al. (1988) to define a pnr threshold value to discriminate between negative and positive samples.

Mean (m1) and standard deviation (s1) of the pnr values of all apparently healthy fish were calculated. Values greater than $\mathrm{m} 1+(2 \times \mathrm{s} 1)$ were then excluded. The mean (m2) and standard deviation (s2) of the remaining values were calculated, and the cut-off pnr 
set at $\mathrm{m} 2+(3 \times \mathrm{s} 2)$. Samples giving a pnr above this threshold were considered positive.

\section{RESULTS}

\section{Comparison of microplate coating methods}

The pnr values of all samples from apparently healthy fish, as determined in the 2 assays using different coating methods, are plotted against each other in Fig. 1. The pnr values from the assay using direct virus coating are generally higher and extend over a wider

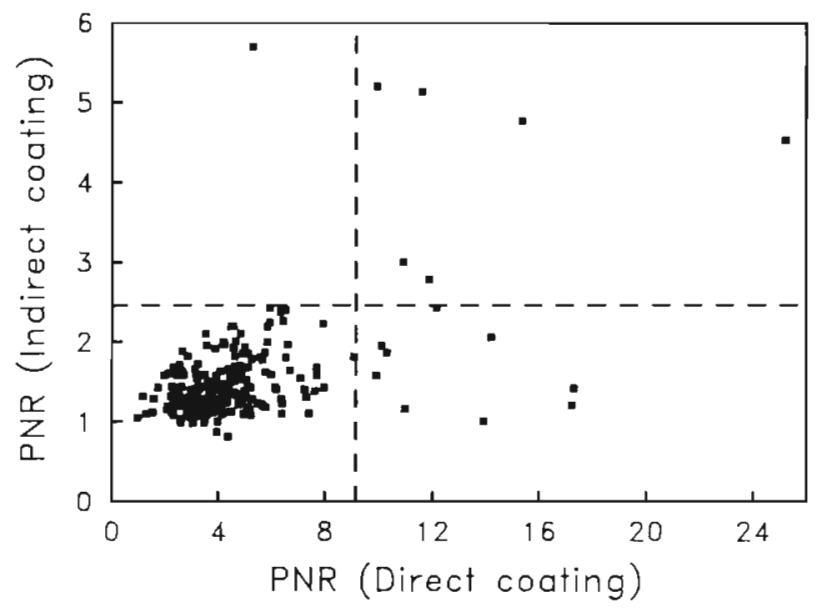

Fig. 1 Platichthys flesus. Comparison of pnr values from the 2 assays using different microtiter plate coating methods. Data points are individual fish not showing signs of disease; positive-negative cut-off pnr values are indicated by broken lines

range than those from the assay using indirect coating with antibodies to capture the virus.

The positive-negative discriminants for the 2 coating methods are illustrated by broken lines. Samples negative by both methods, having a pnr below the thresholds, form a cluster in the lower left quadrant of the figure. A small number of samples show a distinctly high pnr in one or both tests. Samples in the upper right quadrant are positive according to both assays, those in the lower right and upper left quadrant are positive in only one of the assays. A number of samples are positive in the assay using direct virus coating, but remain negative in the assay using indirect coating with antibodies, where they showed high absorbances in both virus-coated and non-coated wells. Only one sample is positive in the latter assay, but negative in the assay using direct virus coating.

Indirect coating using rabbit $\gamma$-globulin to capture virus increased non-specific reactions and therefore lowered the specificity of the assay. Consequently, the assay using direct coating with viral antigen was chosen to determine the prevalence of antibodies to lymphocystis virus (seroprevalence) within the flounder populations.

\section{Antibody activity in fish showing lymphocystis lesions}

A total of 11 fish from both estuaries had lymphocystis lesions. Their pnr values extended up to 35 , but the majority (9) were within the range of apparently healthy fish. Only 4 out of 8 Elbe and 2 out of 3 Eider flounders had antibodies against lymphocystis virus (were seropositive) according to the threshold defined. The pnr values did not correlate with age or size of the fish.

\section{Antibody activity in apparently healthy fish}

A total of 220 apparently healthy fish was tested for antibodies to lymphocystis virus, comprising 149 from the Elbe and 71 from the Eider estuaries. The pnr values of these samples are plotted against the age of fish (1 to $4 \mathrm{yr}$ old only) in Fig. $2 \mathrm{a}$ for the Elbe, and

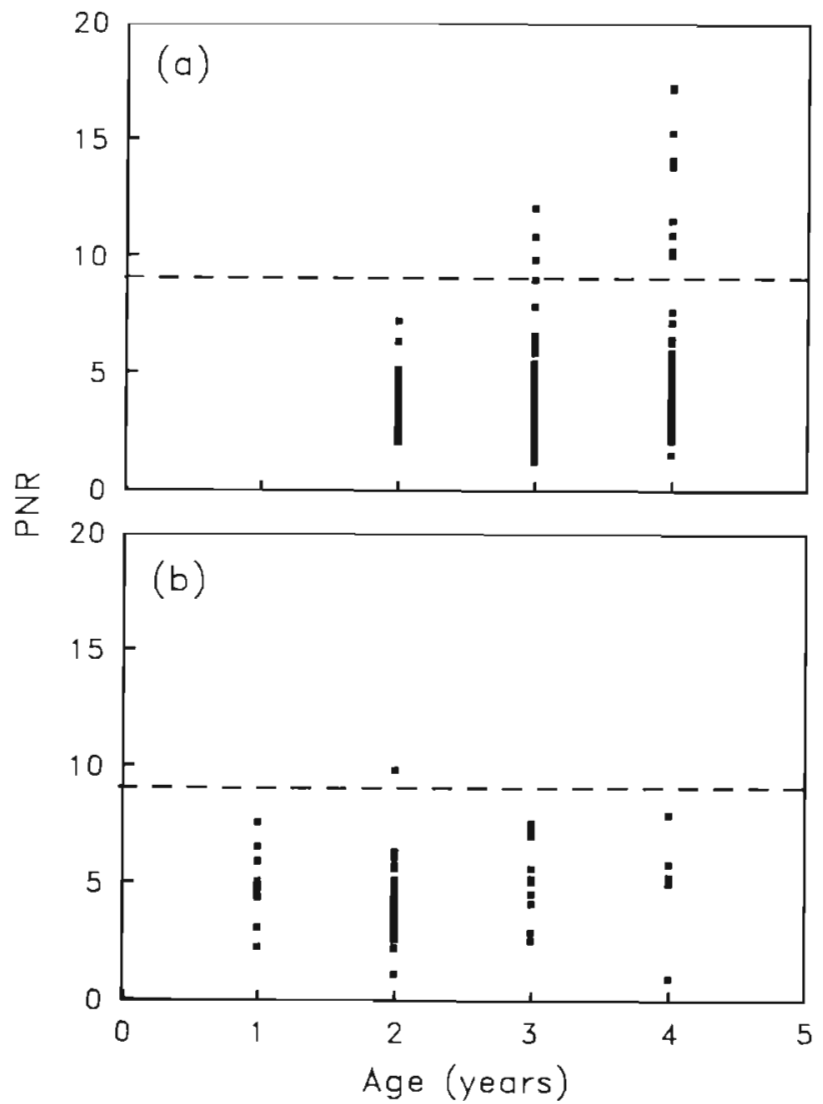

Fig. 2. Platichthys flesus. Results of serological surveys, based on the assay using direct virus coating. Positive-negative ratios plotted against fish age for the Elbe (a) and Eider (b) flounder populations. The pnr cut-off value is indicated by a broken line 
Table 1. Results of serological surveys. Given are seroprevalence values and $95 \%$ confidence intervals (based on the logistic transformation)

\begin{tabular}{|c|c|c|c|c|c|c|c|c|}
\hline \multicolumn{5}{|c|}{ Elbe } & \multicolumn{4}{|c|}{ Eider } \\
\hline $\begin{array}{l}\text { Age } \\
\text { (yr) }\end{array}$ & No. & No. pos. & $\begin{array}{c}\text { Prev. } \\
(\%)\end{array}$ & $\begin{array}{c}95 \% \mathrm{CI} \\
(\%)\end{array}$ & No. & No pos. & $\begin{array}{c}\text { Prev. } \\
(\%)\end{array}$ & $\begin{array}{c}95 \% \text { CI } \\
(\%)\end{array}$ \\
\hline 1 & - & - & - & & 11 & 0 & 0.0 & \\
\hline 2 & 33 & 0 & 0.0 & & 44 & 1 & 2.3 & $0.3-14.5$ \\
\hline 3 & 62 & 3 & 4.8 & $1.5-13.9$ & 10 & 0 & 0.0 & \\
\hline 4 & 52 & 9 & 17.3 & $9.3-30.0$ & 5 & 0 & 0.0 & \\
\hline 5 & - & - & - & & - & - & - & \\
\hline 6 & 2 & 1 & $(50.0)^{\circ}$ & & 1 & 1 & $(100.0)^{\circ}$ & \\
\hline
\end{tabular}

Fig. $2 \mathrm{~b}$ for the Eider populations. Only two 6 yr old flounder were caught in the Elbe estuary and 1 in the Eider estuary. The Eider flounder was antibody positive (pnr value 25.2), and one of the Elbe flounders was also antibody positive (pnr value 11.9 ). The seroprevalence data of the 2 populations are given in Table 1.

\section{DISCUSSION}

The use of rabbit $\gamma$-globulin to coat microtiter plates, with subsequent capture of lymphocystis virus (indirect virus coating), was found to increase non-specific binding of flounder Ig, thus frequently obscuring specific antibody activity to the virus. Only 7 fish were seropositive in assays using indirect virus coating, whereas 15 fish were seropositive in assays using direct virus coating. Direct coating of viral antigen is therefore recommended for similar studies, where possible.

Only 6 out of 11 samples from visibly infected flounders were seropositive. This may reflect the observation of Roberts (1975), that a strong immune response develops only late in the pathogenesis of lymphocystis disease.

The presence of antibodies to lymphocystis virus in a number of apparently healthy fish strongly suggests that recovery from the disease is common in the populations studied. It is not possible, however, to estimate disease induced mortality from these data alone.

The seroprevalence data for the Elbe and Eider populations were presented separately to avoid environmental or other factors specific to each estuary or population influencing the results. In the Elbe population, both seroprevalence and antibody activity in seropositive fish increased with age. The apparent absence of this pattern in the Eider population probably reflects differences in the age structure of sampled fish. Eider samples are dominated by 1 and 2 yr old fish, with very few older individuals. Therefore it is not possible to draw conclusions on differences in sero- prevalence between the 2 populations. To make such comparisons, it is necessary to sample larger numbers of 3 yr old, and older fish.

It is not clear whether high antibody activity alone corresponds to complete protective imunity. If this was the case, the proportion of susceptible fish in the population would decrease with age, and this should lead to a comparatively low prevalence of lymphocystis in old fish. In the Elbe population, prevalence of clinical lymphocystis increases with length in small and medium sized flounder, but decreases in very large fish (Anders 1989). This supports the suggestion that protective immunity is developed.

Acknowledgements. The serological sampling was made possible by the cooperation of Drs Kerstin Anders, Horst Büther and Angela Köhler-Günther. Michael Kerstan advised on otolith reading. K.L. was partially supported by the 'Gesellschaft zur Förderung des Instituts für Meereskunde', Germany.

\section{LITERATURE CITED}

Anders, K. (1989). Lymphocystis disease of fishes. In: Ahne, W., Kurstak, D. (eds.) Viruses of lower vertebrates. Springer, Heidelberg, p. 141-160

Bourne, F. J. (1969). IgA immunoglobulin from porcine serum. Biochem. Biophys. Res. Commun. 36: 138-1.45

Clark, M. F., Adams, A. N. (1977). Characteristics of the microplate method of enzyme-linked immunosorbent assay for the detection of plant viruses. J. gen. Virol. 34: $475-483$

Darai, G., Anders, K, Koch, H. G., Delius, H., Gelderblom, H., Samalecos, C., Flügel, R. M. (1983). Analysis of the genome of fish lymphocystis disease virus isolated directly from epidermal tumors of Pleuronectes. Virology 126 : 466-479

Dixon, P. F. Hill, B. J. (1984). Rapid detection of fish rhabdoviruses by the enzyme-linked immunosorbent assay (ELISA). Aquaculture 42: 1-12

Margenau, T L., Schram, S. T., Blust, W H. (1988). Lymphocystis in a walleye population. Trans. Am. Fish. Soc. 117: 308-310

Masoero, L., Ercolini, C., Caggiano, M., Rossa, A. (1986) 
Osservazioni preliminari sulla linfocisti in una maricoltura intensiva italiana. Riv, ital Pisic. Ittiopat. 21.70-74

Matsusato, $T$ (1975). Lymphocystis disease in cultured yellowtail Seriola quinqueradiata. Fish Path. 10:90-93

Paperna, I., Sabnai, I., Colorni, A. (1982). An outbreak of lymphocystis in Sparus aurata L in the Gulf of Aqaba, Red Sea. J. Fish. Dis. 5: 433-437

Parkinson, R. M., Conradie, J. D., Miller, L. V., Marimuthu, T (1988). The interpretation of ELISA results by means of the standard deviation ratio. J. immun. Meth. 115: 105-110

Roberts, R. J. (1975). Experimental pathogenesis of lymphocystis in the plaice (Pleuronectes platessa). In: Page, L. A. (ed.) Wildlife diseases. Plenum Press. New York, p. $431-441$

Responsible Subject Editor: W. Ahne, München, Germany
Russell, P. H. (1974). Lymphocystis in wild plaice (Pleuronectes platessa) and flounder (Platichthys flesus) in British coastal waters. A histopathological and serological study. J. Fish Biol. 6: 771-778

Ryder, R. A. (1961). Lymphocystis as a mortality factor in a walleye population. Progve Fish Cult. 23: 183-186

Tanaka, M., Yoshimizu, M., Kusakari, M., Kimura, T (1984). Lymphocystis disease in kurosoi Sebastes schlegeli and hirame Paralichthys olivaceus in Hokkaido, Japan. Bull. Jap. Soc. scient Fish. 50:37-42

Wolf, K. (1962). Experimental propagation of lymphocystis disease of fishes. Virology 18: 249-256

Wolf, K. (1988). Fish viruses and fish viral diseases. Cornell University Press, Ithaca

Manuscript first received: February 15, 1990

Revised version accepted: May 31, 1991 